\begin{tabular}{|l|l|}
\hline Jurnal Bimbingan dan Konseling Ar-Rahman \\
Volume 5, Nomor 1,Tahun 2019 \\
Tersedia Online: http://ojs.uniska.ac.id/index.php/BKA \\
e-ISSN 2477-6300
\end{tabular}

\title{
MEMAHAMI RASA INGIN TAHU REMAJA DITINJAU BERDASARKAN JENIS KELAMIN
}

\author{
Indra Prapto Nugroho \\ Program Studi Psikologi, Fakultas Kedokteran, Universitas Sriwijaya \\ Email: ipnugroho@fk.unsri.ac.id
}

\begin{abstract}
ABSTRAK
Abstrak Rasa ingin tahu diprediksi membantu remaja terus belajar dan tumbuh kembang didalam kehidupan. Rasa ingin tahu dapat digambarkan melalui sikap antusias remaja dengan mengamati, mendengar, mencari, dan menggali informasi untuk memperoleh kepastian akan kebenaran. Keingintahuan mengakibatkan remaja mendapatkan informasi baru yang memungkin remaja memiliki keyakinan dan termotivasi untuk mengeksplorasi lebih jauh perihal keingintahuannya. Tujuan penelitian ini adalah untuk mengetahui perbedaan rasa ingin tahu remaja ditinjau berdasarkan jenis kelamin. Metode yang digunakan adalah pendekatan kuantitatif komparatif dengan menggunakan uji beda dengan penentuan sampel yang digunakan pada penelitian ini harus disesuaikan dengan tujuan peneliti yakni termasuk dalam kategori remaja akhir dengan jumlah partisipan sebanyak 50 remaja laki-laki dan 50 remaja perempuan. Pengumpulan data dalam penelitian ini adalah menggunakan Curiosity and Exploration Inventory yang diadaptasi oleh Kashdan, Rose \& Finchan (2004) dengan model skala Likert yang dianalisa menggunakan uji hipotesis independent sample t-test. Hasil penelitian menunjukkan bahwa nilai $\mathrm{t}$ 2,088 dan uji signifikansi menunjukkan $0,004<0,05$ artinya ada perbedaan rasa ingin tahu yang signifikan antara remaja laki-laki dan perempuan.
\end{abstract}

Kata Kunci: Rasa Ingin Tahu; Remaja; Jenis Kelamin

\section{ABSTRACT}

Abstract Curiosity is predicted, helping teenagers continue to learn and grow in life. Curiosity can be illustrated through the enthusiasm of teenagers by observing, listening, searching, and digging for information to obtain certainty about the truth. Curiosity causes teenagers to get new information that allows them to have confidence and be motivated to explore further about their curiosity. The purpose of this study was to determine differences in curiosity of teenagers by gender. The method used is a comparative quantitative approach using a different test with the determination of the sample used in this study must be adjusted to the objectives of the researcher that is included in the category of late teenagers with the number of participants is 50 boys and 50 girls. The data collection in this study was using the Curiosity and Exploration Inventory which was adapted by Kashdan, Rose \& Finchan (2004) with a Likert scale model analyzed using hypothesis testing independent sample t-test. The results showed that the value of $t$ was 2.088 and the significance test showed $0.004<0.05$, meaning there is a significant difference in curiosity between boys and girls.

Keywords: Curiosity; Teenagers; Gender

Dipublikasikan Oleh :

UPT Publikasi dan Pengelolaan Jurnal

Universitas Islam Kalimantan Muhammad Arsyad Al-Banjari Banjarmasin 


\section{PENDAHULUAN}

Manusia merupakan makhluk sosial yang cerdas dikarenakan kemampuannya untuk berpikir menggunakan akalnya. Tentunya antara laki-laki dan perempuan memiliki cara pandang yang berbeda (Nurhayati, 2016). Seringkali perbedaan menimbulkan dorongan untuk bisa merubah dirinya terus menjadi yang terbaik. Dalam proses mencapai hal tersebut pentingnya rasa ingin tahu menjadi suatu kebutuhan yang dimana rasa ingin tahu merupakan perwujudan dari sikap antusias individu dengan berperilaku mengamati, mendengar, mencari, dan menggali informasi untuk memperoleh kepastian akan kebenaran terhadap fenomena ataupun objek yang ada dimasyarakat.

Pentingnya rasa ingin tahu membuat manusia untuk terus belajar dan berkembang didalam kehidupannya. Keingintahuan mengakibatkan manusia memperoleh suatu keyakinan akan kebenaran terhadap suatu hal yang baru. Menurut Marvin \& Shohamy (2016) bahwa rasa ingin tahu mengakibatkan seseorang termotivasi untuk berkembang dan belajar serta bermanfaat untuk meningkatkan penyimpanan informasi dalam memori jangka panjang. Terkadang bahwa rasa ingin tahu sangat diperlukan khususnya pada setiap orang yang ingin mendalami keahliannya misalnya pada remaja akhir, rasa ingin tahu sangat diperlukan untuk menunjang diri mereka dalam mempersiapkan memasuki dunia pekerjaan.

Secara emosi, remaja memiliki tingkat kematangan emosional yang cukup baik dan cara proses berpikir yang berbeda antara individu satu dengan individu lainnya. Remaja memiliki kebebasan untuk berpendapat, berperan serta menyampaikan ide kreatifitasnya guna mengembangkan kemampuan dan keilmuannya untuk berperan di masyarakat. Menurut Garrosa, Blanco, Carmona, \& Moreno (2016) bahwa rasa ingin tahu mengakibatkan seseorang merasakan dirinya bermakna didalam kehidupannya. Tentunya jika remaja memiliki rasa ingin tahu yang tinggi maka ia akan termotivasi melalui rasa ingin tahunya untuk bisa mengembangkan potensi yang dimilikinya. Hasil dari potensi yang dihasilkan dapat berupa nilai prestasi akademik yang baik, kepuasan, adanya motivasi dalam belajar serta harga diri yang tinggi. Menurut Froiland, Mayor \& Herlevi (2015) bahwa rasa ingin tahu mampu memprediksi remaja untuk melihat sejauh mana motivasi siswa ketika belajar. Disamping itu juga bahwa rasa ingin tahu akan membuat remaja memiliki prestasi akademik yang tinggi.

Perilaku ingin tahu merupakan dorongan yang ditimbulkan secara naluriah bagi setiap orang untuk belajar dan berkembang. Didalam proses belajar tersebut manusia diberikan kemampuan indera untuk mampu berpikir dan peka dalam berbagai hal. Rasa ingin tahu membuat setiap orang untuk proaktif menanggapi rangsangan dan aktivitas mengenai sesuatu hal yang baru, menantang, dan memerlukan kemampuan berpikir yang kompleksitas.

Menurut Kashdan, Rose \& Finchan (2004) rasa ingin tahu terbagi kedalam dua hal, yakni: a). Rasa ingin tahu yang bersifat aktif dalam mencari berbagai hal yang baru, b). Rasa ingin tahu untuk mendalami suatu hal tertentu secara konkret. Pentingnya rasa ingin tahu mampu mendorong terjadinya suatu kontak rangsangan mengenai sesuatu hal yang baru dan peluang yang ditimbulkan untuk memperoleh kebenaran informasi yang konkret. Selain itu, beberapa kajian literatur telah dibuktikan pada penelitian Kashdan, Rose \& Finchan (2004) bahwa rasa ingin tahu akan membuat seseorang termotivasi, serta menemukan pandangan yang baru mengenai sesuatu hal dalam berbagai sudut pandang.

Terdapat beberapa pendekatan mengenai munculnya stimulus rasa ingin tahu, yakni yang dijabarkan oleh Kashdan, Rose \& Finchan (2004) diantaranya adalah a) peningkatan alokasi perhatian untuk mengamati dan menyesuaikan diri terhadap rangsangan yang diberikan, b) adanya manfaat yang diperoleh dari hasil kognitif serta perilaku, c) keterlibatan manfaat rangsangan-rangsangan stimulus dari kegiatan yang dilakukan, d) adanya suatu integrasi pengalaman-pengalaman yang diperoleh dalam proses belajar.

Pendapat lain oleh Berlyne (1971) bahwa rasa ingin tahu akan mengakomodasikan pemikiran dan keterlibatan seseorang diperoleh dari stimulus kebaruan, kompleksitas, ketidakpastian, dan konflik. Hal ini sesuai dengan penelitian oleh Kashdan \& Roberts (2004) bahwa rasa ingin tahu merupakan dorongan emosi positif untuk mengejar, menuju, dan memperoleh pengalaman yang mengesankan. Beberapa stimulus yang diberikan memiliki manfaat bahwa seseorang yang memiliki rasa ingin tahu yang tinggi akan lebih mudah untuk aktif dan berpartisipasi untuk memperoleh pengalaman baru di sepanjang kehidupannya.

Lemahnya kesadaran akan pentingnya rasa ingin tahu membuat aspek ini sering kali dilupakan bahkan dikucilkan dimasyarakat. Beberapa orang menyadari bahwa belajar akan dapat diperoleh di berbagai proses kehidupan, namun menurut Watson (1988) rasa ingin tahu sangat penting untuk dikembangkan dengan tujuan membina hubungan dilingkungan sosial masyarakat secara aktif dan sebagai fasilitas untuk memperoleh kepuasan dalam hidup.

Kashdan \& Roberts (2004) berpendapat banyaknya kasus mengenai kecemasan dalam berhubungan dilingkungan sosial diakibatkan dari lemahnya individu untuk bisa menerima dan melakukan eksplorasi mengenai informasi. Kecemasan yang berlebihan membuat beberapa orang 
menghindari penggalian informasi yang menantang dan melihat peluang diberbagai kesempatan yang ada. Studi kasus yang disebutkan oleh McGillivray, Murayama, \& Castel (2015) bahwa lemahnya daya mengingat dan penyimpanan informasi di memori seringkali membuat orang dewasa merasa kesulitan dalam penggalian informasi. Dengan kemampuan rasa ingin tahu menurut Castel (2008) adalah salah satu kemudahan yang dilakukan orang dewasa untuk melatih kemampuan daya ingatnya dan melakukan proses penyimpanan informasi di otaknya.

Hasil penelitian oleh Ekawati dan Wulandari (2011) menunjukan bahwa perempuan pada umumnya lebih baik didalam proses mengingat dan laki-laki memiliki kemampuan lebih baik untuk melakukan proses berpikir secara logis. Sesuai dengan pernyataan oleh Santrock (2007) yang menjelaskan bahwa ada perbedaan dimensi sosiokultural dan psikologis antara laki-laki dan perempuan terhadap hasil prestasi belajar.

Penelitian yang berbeda menunjukan bahwa tidak adanya perbedaan rata-rata rasa ingin tahu siswa perempuan dengan siswa laki-laki (Raharja, Wibhawa, \& Lukas, 2018). Jika kita mengaitkan dengan konsep Incongruity Theories menyatakan bahwa rasa ingin tahu adalah usaha untuk memahami dunia dengan bersifat tidak konstan dan saling memiliki keterkaitan dari akibat yang diterimanya. Ada beberapa bias perilaku didalam proses pembelajaran dikelas yang didasari perbedaan antara remaja laki-laki dan perempuan adalah (1) anak perempuan memiliki sifat patuh, diam dan lebih sabar dari pada laki-laki yang cenderung ribut dan suka mencari perhatian, (2) tanpa disadari guru lebih memperhatikan anak laki-laki yang sering meminta penjelasan dan instruksi yang jelas daripada perempuan (Santrock, 2007).

Berdasarkan uraian diatas tujuan dari penelitian ini adalah untuk mengetahui seberapa besar perbedaan rasa ingin tahu remaja ditinjau berdasarkan jenis kelamin. Adapun manfaat yang diperoleh dari penelitian ini bahwa perlunya menyikapi dan mengoptimalkan rasa ingin tahu terhadap suatu hal yang baru akan mampu memberikan kontribusi terhadap pengembangan potensi diri serta menjadikan pengalaman sebagai suatu ilmu yang akan bermanfaat dikemudian hari.

\section{METODE}

Rancangan Penelitian ini menggunakan penelitian non-experimental dengan jenis penelitian kuantitatif komparatif dengan menggunakan uji beda. Karena peneliti ingin mengetahui seberapa besar perbedaan rasa ingin tahu pada remaja yang berjenis kelamin laki-laki dan perempuan.Subjek yang digunakan adalah kategori remaja akhir dengan jumlah subjek yang akan diminta untuk sebagai partisipan dalam penelitian ini sebanyak 100 orang, yang terdiri dari 50 laki-laki dan 50 perempuan.

Metode pengumpulan data dalam penelitian ini adalah menggunakan Curiosity and Exploration Inventoryyang dikembangkan oleh Kashdan, et.al(2009) dengan model skala Likert dan nilai reliabilitas Curiosity and Exploration Inventoryadalah sebesar 0,826. Dengan demikian, nilai Reliabilitas yang dimiliki pada Curiosity and Exploration Inventorymampu melakukan pengukuran terhadap rasa ingin tahu remaja.

Analisa data yang digunakan dalam penelitian ini menggunakan uji analisisindependent sample t-test yang digunakan untuk menguji apakah dua sampel yang tidak berhubungan berasal dari populasi yang mempunyai mean sama atau yang tidak secara signifikan(Sugiyono, 2012).

Hipotesis: ada perbedaan rasa ingin tahu antara remaja laki-laki dan remaja perempuan

\section{HASIL DAN PEMBAHASAN}

Penelitian yang dilakukan kepada 100 remaja, yang terdiri dari 50 partisipan remaja laki-laki dan 50 partisipan remaja perempuan menunjukan hasil sebagai berikut:

Tabel 1. Hasil analisis t-test

\begin{tabular}{|c|c|c|c|c|c|}
\hline Remaja & $\mathbf{N}$ & Mean & $\mathbf{T}$ & Sig & Keterangan \\
\hline Laki-laki & 50 & 36.40 & \multirow[b]{2}{*}{2.088} & \multirow[b]{2}{*}{0.004} & \multirow[b]{2}{*}{ Signifikan } \\
\hline Perempuan & 50 & 33.76 & & & \\
\hline
\end{tabular}

Hasil uji hipotesa pada tabel 1yang didasarkanpada analisa data dengan melakukan uji t, diperoleh bahwa nilai $t$ sebesar 2,088 dan uji signifikansi menunjukan $0.004<0.05$ berarti bahwa ada perbedaan yang signifikan antara rasa ingin tahu remaja laki-laki dan remaja perempuan. Selain itu, dapat diketahui bahwa nilai rata-rata rasa ingin tahu pada remaja laki-laki adalah sebesar 36,40 lebih tinggi

Dipublikasikan Oleh :

UPT Publikasi dan Pengelolaan Jurnal

Universitas Islam Kalimantan Muhammad Arsyad Al-Banjari Banjarmasin daripada remaja perempuan dengan nilai rata-rata rasa ingin tahu hanya sebesar 33,76.

Keinginan untuk mencoba sesuatu hal yang baru bagi setiap individu tentunya memiliki persepsi dan pendapat yang berbeda-beda antar individu satu dengan individu yang lainnya. Rasa ingin tahu dapat muncul jika seseorang tertarik terhadap suatu hal yang unik, menantang, serta manfaat yang diperolehnya. 
Menurut Galupo \& Esterline (2013) bahwa perempuan dan laki-laki memiliki performa yang berbeda dalam keterlibatan untuk menafsirkan sesuatu hal yang baru diketahuinya.

Secara signifikan bahwa laki-laki cenderung lebih dapat dengan mudah berpartisipasi daripada perempuan. Hal ini diakibatkan karena laki-laki memiliki emosional yang tinggi dan laki-laki ingin menunjukan kelebihannya terhadap lawan jenisnya. Pernyataan tersebut didukung oleh Hurlock (2004) yang menjelaskan menganai daya tarik fisik merupakan bagian terpenting dalam memperoleh dukungan sosial, popularitas dan hubungan pertemanan.

Ketika disinggung mengenai masa perkembangan, seringkali pola asuh diikutsertakan terhadap kemampuan rasa ingin tahu pada anak. Menurut Abudulbouh (2016) didalam penelitiannya yang mengikutsertakan 350 siswa sekolah dasar pada kelas lima dan kelas enam terdapat pengaruh rasa ingin tahu terhadap pola asuh orang tua. Studi kasus tersebut menemukan bahwa pola asuh demokrasi pada anak laki-laki mengakibatkan anak cenderung memiliki rasa ingin tahu yang tinggi. Anak yang di asuh dengan pola asuh demokrasi memungkinkan anak diberikan kesempatan untuk memilih, menentukan, menyelesaikan masalah secara mandiri dan mampu bertanggung jawab terhadap apa yang diperbuatnya.

Menurut Hurlock (2004) pola asuh demokratis memungkinkan orang tua untuk dapat berpikir rasional dan realistis terhadap kemampuan anaknya untuk memberikan kebebasan memilih serta melakukan pendekatan yang efektif terhadap anak. Dimana pada masa perkembangan, seorang anak yang dididik dengan pola asuh demokratis akan memberikan banyak kesempatan untuk anak tersebut menentukan, memilih serta berdiskusi terhadap suatu hal yang baru dan peran orang tua sebagai pengendali dan petunjuk terhadap tumbuh kembang anak.

Dengan demikian bahwasanya rasa ingin tahu bermanfaat bagi individu untuk membuka, menambah, dan mengembangkan potensi yang dimilikinya untuk berani bersaing, terbuka, dan meningkatkan kemampuannya melalui rasa ingin tahu.

\section{PENUTUP}

Berdasarkan hasil yang diperoleh dalam penelitian ini bahwa antara laki-laki dan perempuan memiliki perbedaan yang signifikan mengenai rasa ingin tahu terhadap suatu hal yang baru. Hal ini diakibatkan bahwa pola asuh orang tua menjadi salah satu penentu terhadap perilaku yang ditimbulkan anak untuk mencari, mempelajari, menggali, mengamati , mengembangkan, meningkatkan potensinya melalui perilaku rasa ingin tahu.
Dalam pendidikan mengenai masa perkembangan anak, sangat disarankan bahwa orang tua seharusnya menerapkan perilaku pola asuh demokratis yang memacu anak tumbuh dan berkembang secara mandiri, serta menjadikan sesuatu hal yang baru sebagai sesuatu hal yang unik dan harus sipahami secara mendalam.

Jika dilihat mengenai perbedaan jenis kelamin, bahwa anak laki-laki lebih bersifat dominan dan memiliki antusias yang cukup tinggi terhadap rasa ingin tahunya mempelajari hal yang baru. Karena anak laki-laki memiliki emosional yang tinggi serta suka terhadap suatu hal yang menantang ataupun menarik untuk dicoba (Nurhayati, 2016).

Implikasi dari penelitian ini diharapkan bahwa perlu kiranya pada penelitian selanjutnya untuk menguji dan mengaitkan rasa ingin tahu terhadap kemampuan kreativitas antara laki-laki dan perempuan. Hal ini dikarenakan kreativitas dapat terjadi dari akibat rasa ingin tahu dan akan menimbulkan suatu ide cemerlang terhadap kreativitas yang dihasilkannya. Tidak lupa juga bahwa kiranya pada penelitian selanjutnya mampu menjelaskan lebih secara detail mengapa anak perempuan lebih cenderung atau kurang berminat terhadap mencari rasa ingin tahu sesuatu hal yang belum dikenali ataupun dipahami sebelumnya.

\section{REFERENSI}

Abudulbouh, M. A. (2016). The Relationship Between The Forms of Family Upbringing and Curiosity: A Study On Primary School Students In Zarqa First Directorate of Education In Jordan. International Journal of Education And Research, Vol. 4 - 1

Berlyne, D. E. (1971). Aesthetics and psychobiology. New York: Appleton-Century-Crofts

Castel, A. D. (2008). The adaptive and strategic use of memory by older adults: Evaluative processing and value-directed remembering. In A. S. Benjamin \& B. H. Ross (Eds.), The psychology of learning and motivation Vol. 48, pp. 225-270. London, United Kingdom: Academic Press.

Ekawati, A.\& Wulandari, S. (2011). Perbedaan Jenis Kelamin Terhadap Kemampuan Siswa Dalam Mata Pelajaran Matematika(Studi Kasus Sekolah Dasar). Jurnal SOCIOSCIENTIA Kopertis Wilayah XI Kalimantan, Vol 3. No 1. Universitas Borneo Tarakan.

Froiland, J. M, Mayor, P. \& Herlevi, M. (2015). Motives emanating from personality associated with achievement in a Finnish senior high school: Physical activity, curiosity, and family motives. Journal ofSchool Psychology International, pp. 1-15 
Galupo, M. P., \& Esterline, K. M. (2013). "Drunken Curiosity" and "Gay Chicken" Gender Differences in Same-Sex Performattivity. Journal of Bisexuality Vol.13 pp. 106-121

Garrosa, E., Blanco-Donoso, L.M., Carmona-Cobo, I. \& Moreno-Jimenez, B. (2016). How do Curiosity, Meaning in Life, and Search for Meaning Predict College Student's Daily Emotional Exhaustion and Engagement?. Journal of Happiness Studies, Vol. 17 pp. 1-24

Hurlock, E. (2004). Psikologi Perkembangan: Suatu Pendekatan Sepanjang Rentang Kehidupan. Jakarta: Erlangga

Kashdan, T. B, Rose, P., \& Finchan, F.D. (2004). Curiosity and Exploration: Facilitating Positive Subjective Experiences and Personal Growth Opportunities. Journal of Personality Assessment, Vol. 82(3), pp. 291-305

Kashdan, T. B. \& Roberts, J. E. (2004). Traits And State Curiosity In The Genesis Of Intimacy: Differentiation From Related Construct. Journal of Social and Clinical Psychology, Vol. 23, No. 6, pp. 792-816

Kashdan, T. B., Gallagher, M. W., Silvia, P. J., Winterstein, B. P., Breen, W. E., Terhar, D., \&Steger, M. F. (2009). The Curiosity and Exploration Inventory-II. Development, factor structure, and psychometrics. Journal of Research in Personality, Vol 43, pp. 987-998

Marvin, C. B \& Shohamy, D. (2016). Curiosity and reward : Valence predicts choice and information prediction errors enhance learning. Journal of
Experimental Psychology, Vol. 145 (3) p. 266272

McGillivray, S., Murayama, K., \& Castel, A. D. (2015). Thirst for Knowledge: The Effects of Curiosity and Interest on Memory in Younger and Older Adults. Psychology and Aging. Advance online publication. http://dx.doi.org/10.1037/a0039801

Nurhayati, E. (2016). Memahami Psikologis Perempuan (Integrasi \& Intercomplementer Perspektif Psikologi dan islam). Batusangkar International Conference. Integration and Interconnection of Science " The Reflection of Islam Kabbah” pp. 245-258.

Raharja, S., Wibhawa, M.R., \& Lukas, S. (2018). Mengukur Rasa Ingin Tahu Siswa (Measuring Students Curiosity). A Journal of language, Literature, Culture, and Education POLYGLOT. Vol.14, No.2

Santrock.2007. Perkembangan Anak (Jilid 2). Jakarta : Erlangga

Sugiyono. (2012). Metode Penelitian Pendidikan Pendekatan Kuantitatif, Kualitatif dan R\&D. Bandung: Alfabeta.

Watson, D. (1988). The vicissitudes of mood measurement: Effects of varying descriptors, time frames, and response formats on measures of positive and negative affect. Journalof Personality and Social Psychology, 55, pp. 128141.

Dipublikasikan Oleh :

UPT Publikasi dan Pengelolaan Jurnal

Universitas Islam Kalimantan Muhammad Arsyad Al-Banjari Banjarmasin 